\title{
Recurrent Wheezing in Infants and Young Children and Bronchial Hyper- Responsiveness
}

\section{Russell J Hopp}

Professor of Pediatrics and Medicine, Creighton University, USA

*Corresponding author: Russell J Hopp, Professor of Pediatrics and Medicine, Creighton University, USA, E-mail: RUSSELLHOPP@creighton.edu

Received date: May 11, 2016; Accepted date: August 03, 2016; Published date: August 09, 2016

Copyright: $\odot 2016$ Hopp RJ. This is an open-access article distributed under the terms of the Creative Commons Attribution License, which permits unrestricted use, distribution, and reproduction in any medium, provided the original author and source are credited.

Keywords: Wheezing in infants; Syncytial infection; Corticosteroid

\section{Commentary}

Since the publication of a Review in 2003, the wheezing phenotypes discussed have largely persisted in the vernacular and understanding of the concept of the recurrently wheezing child [1].

Childhood wheeze is a common phenomenon, and has seasonal prominence, largely focused on a viral respiratory syncytial infection (RSV). When children wheeze again, or repeatedly, and a RSV infection was previously documented, a ready explanation is available. Recent data strongly supports the likelihood of rhinovirus as the agent for the next sequence wheeze, and with the recurrent wheeze a risk for asthma development [2]. Without a RSV vaccination this postbronchiolitis wheezer will fit the profile offered in the original review. There remains however, as mentioned in 2003, a concern these postbronchiolitis wheezers can morph into asthma, and a recent study suggest a genetic association [3]. This "phenotype" was more recently discussed, but termed "severe intermittent wheeze" [4]. Atopic features and eventual asthma, however was not uncommon in the phenotype discussed. It seems the medical community in 2016 still struggles with the post-RSV phenotype.

If a recurrently wheezing child has asthma, but is less than 6 years old, the advancement in proving this fact is still limited. Clearly these children have asthma symptoms, many are atopic, and many respond to asthma treatment. Using asthma predictive index type risks defined at age 6 [5], might, however, prove useful in a new protocol to attempt to define children at a younger age who then have asthma at age 6, possibly supported by measure(s) of airway responsiveness. As of yet, no inhaled corticosteroid-long acting bronchodilator therapy is approved below age 6 , although these conventional asthma medications are used routinely.

Advancement in measuring airway hyper-responsiveness in asthmatic infants and young children has no further recent advancements. Measuring reversibility to inhaled bronchodilators is a reverse of measuring bronchoconstriction to methacholine. Even this simple concept is rarely considered until school-age.
Smaller airways in smoking associated children as originally shown by Martinez et al. [6], has been further defined using another airway measure, Feno. Infants exposed to intrauterine smoke had a decreased mixed nasal/lung Feno, as compared to never smoked infants or those only with post-natal smoke exposure [7]. These studies suggest a different pathway for small airways with potential recurrent wheeze, as compared to post-RSV wheeze or asthma pathway.

The management of young children with recurrent wheezing was recently reviewed [8]. No data was provided to "tease" out the different phenotypes discussed in 2003 [1]. If, the child is managed as an "asthmatic" key concerns for their care was extrapolated from the National Heart Lung and Blood Asthma Research Networks [8].

\section{References}

1. Hopp RJ (2003) Recurrent wheezing in infants and young children and bronchial hyperresponsiveness: a perspective. Clin Rev Allergy Immunol 24: 7-18

2. Kim WK, Gern JE (2012) Updates in the relationship between human rhinovirus and asthma. Allergy Asthma Immunol Res 4: 116-121.

3. Caliskan M, Bochkov YA, Kreiner-Moller E, Bonnelykke K, Stein MM, et al. (2013) Rhinovirus wheezing illness and genetic risk of childhoodonset asthma. N Engl J Med 368: 1398-1407.

4. Bacharier LB, Phillips BR, Bloomberg GR, Zeiger RS, Paul IM, et al. (2007) Severe intermittent wheezing in preschool children: a distinct phenotype. J Allergy Clin Immunol 119: 604-610.

5. Castro-Rodríguez JA, Holberg CJ, Wright AL, Martinez FD (2000) A clinical index to define risk of asthma in young children with recurrent wheezing. Am J Respir Crit Care Med 162: 1403-1406.

6. Martinez FD, Wright AL, Taussig LM, Holberg CJ, Halonen M, et al. (1995) Asthma and wheezing in the first six years of life. The Group Health Medical Associates. N Engl J Med 332: 133-138.

7. Gabriele C, Asgarali R, Jaddoe VW, Hofman A, Moll HA, et al. (2008) Smoke exposure, airway symptoms and exhaled nitric oxide in infants: the Generation R study. Eur Respir J 32: 307-313.

8. Beigelman A, Bacharier LB (2016) Management of Preschool Children with Recurrent Wheezing: Lessons from the NHLBI's Asthma Research Networks. J Allergy Clin Immunol Pract 4: 1-8. 